Biological and Clinical Sciences Research Journal

ISSN: 2708-2261

www.bcsrj.com

DOI: https://doi.org/10.54112/bcsri.v2020i1.20

Biol. Clin. Sci. Res. J., Volume, 2020: 20

MEDEYE

Original Research

\title{
GENETIC VARIABILITY AND ASSOCIATION AMONG SEEDLING TRAITS OF ZEA MAYS UNDER DROUGHT STRESS CONDITIONS
}

\author{
HASEEB A, NAWAZ A, RAO MQA, *ALI Q, MALIK A
}

\author{
Institute of Molecular Biology and Biotechnology, The University of Lahore, Lahore, Pakistan \\ Corresponding author: saim1692@gmail.com
}

(Received, $5^{\text {th }}$ May 2020, Revised $14^{\text {th }}$ August 2020, Published 25 $5^{\text {th }}$ August 2020)

\begin{abstract}
Maize is an important food crop for human and feed for animals or livestock. It is highly sensitive for abiotic and biotic stress conditions. An experiment was conducted in the greenhouse of Institute of Molecular Biology and Biotechnology, The University of Lahore for the determination of effects of drought on maize growth related seedling traits. Four maize genotypes/varieties viz., B-316, Raka-poshi, Pak-Afghoi and EV-1097Q were grown to evaluate the effects of drought stress. Four drought treatments were used including 20\% irrigation water, $40 \%$ irrigation water, $60 \%$ irrigation water, $80 \%$ irrigation water, $90 \%$ irrigation water and control or $100 \%$ irrigation water. It was found that the genotypes B-316 and Raka-poshi showed better performance for all studied traits especial shoot and root length as compared with other two genotypes EV-109Q and Pak-Afghoi. The minimum effects of drought were reported at control and 90\% irrigation water. The effects of drought were increased with the increase in concentration of drought stress. The adverse drought effects were reported under the treatment of drought at 20\% and 40\% irrigation water. The higher genetic advance and heritability was recorded for root length, shoot length, dry shoot weight and dry root weight. The significant correlation was recorded between root length, shoot length and dry shoot weight. The higher contribution for shoot length was reported for root length, dry shoot weight and number of roots per plant. It was concluded from study that the selection of maize genotypes on the basis of root length, shoot length and dry shoot weight may be fruitful to produce drought stress tolerance maize hybrids and synthetic varieties.
\end{abstract}

Keywords: maize, drought, genetic advance, heritability, root length, shoot length

\section{Introduction}

Maize is also known as corn in western countries. All grains were known as corn in trade and maize was very famous grain in trade. The corn or maize has been considered as an imperative cereal crop however, with course of the time, the needs of maize has been going to enhance, therefore the need of maize to grow hastily during the short duration for overcoming the malnutrition in human population (Ali et al., 2013). Maize contains oil, sugar, ash, fibres and proteins (Ali et al., 2014; Chaudhary, 1983). The production of grain yield of maize in Pakistan has been low as compared with developed countries due to low seed quality; therefore, a large number of abiotic and biotic environmental factors are there which affect the crop productivity and yield during crop growth periods (Ali et al., 2016; Ali et al., 2012; Buckler et al., 2009). There are significant losses in grain yield of corn or maize has been projected due to drought because of increase in global climate changes among major maize production areas of the world. Maize plant is highly sensitive to drought stress conditions which mainly caused damages at silking, anthesis and grain filling phases of maize crop plants. Maize has been suffered from water deficit or drought between the anthesis as well the grain filling stages of crop plants which caused up to $40-80 \%$ grain yield los, therefore, the drought has been considered as a main or major limiting factor which affects plant development, growth and grain yield of maize (Edreira and Otegui, 2012; Masood et al., 2015; Mupangwa et al., 2007; Mustafa et al., 2013). The need is for the development of such new techniques and varieties to overcome the grain yield losses due to changing global environmental conditions which are included salt, heat, alkalinity, flood and drought stresses (Barnabás et al., 2008; Cakir, 2004; Zubair et al., 2016) also cold, heat and salinity caused losses in corn grain production and mainly affects at anthesis stage (Boomsma et al., 2009; Chai et al., 2016; Farre and Faci, 2006).

Materials and methods

For evaluating maize for drought stress, we have conducted an experiment in the greenhouse of Institute of Molecular Biology and Biotechnology, The University of Lahore, Lahore. Four maize genotypes were selected for our research work, viz.,

[Citation: Haseeb, A., Nawaz, A., Rao, M.Q.A., Ali, Q., Malik, A. (2020). Genetic variability and association among seedling traits of Zea mays under drought stress conditions. Biol. Clin. Sci. Res. J., 2020: 20 doi: https://doi.org/10.54112/bcsrj.v2020i1.20] 
B-316, EV-1097Q, Raka-poshi and Pak-afghoi. The seeds of selected wheat genotypes were sown in 56 pots. Each of the pot was in triplicate for each of the maize genotype. The treatments of drought stress were kept as $20 \%$ irrigation water, $40 \%$ irrigation water, $60 \%$ irrigation water, $80 \%$ irrigation water, $90 \%$ irrigation water and control or $100 \%$ irrigation water. The seeds were sown and after germination, the seedlings were given stress treatments after one week of germination. The salt treatment was carried out through the application of $200 \mathrm{ml}$ water to normal or control plants while calculated amount of water was carried out for stress conditions. The seedling data was recorded for diverse morphological traits, viz., leaf area, roots per plant, dry root weight, root length, shoot length, shoot dry weight. The recorded data was analyzed statistically through the analysis of variance (ANOVA) techniques through using the SPSS23.1 software.

Table 1. Survival percentage of maize genotypes under different drought stress conditions

\begin{tabular}{lllll}
\hline Treatments & B-316 & Raka-poshi & EV-1097Q & Pak-Afghoi \\
\hline Control & 100 & 100 & 100 & 100 \\
20\% irrigation water (T1) & 75.21 & 74.17 & 73.24 & 72.76 \\
$\mathbf{4 0 \%}$ irrigation water (T2) & 78.45 & 76.34 & 77.48 & 74.28 \\
60\% irrigation water (T3) & 81.24 & 80.83 & 76.53 & 76.34 \\
80\% irrigation water (T5) & 87.78 & 86.87 & 78.45 & 79.25 \\
90\% irrigation water (T6) & 89.34 & 90.47 & 80.12 & 81.42 \\
\hline
\end{tabular}

It was revealed from results given in table 2 that significant differences were reported for genotypes, treatments, and interactions between treatments of drought and genotypes. The results revealed that the average leaf area $\left(4.1522 \pm 0.00112 \mathrm{~cm}^{2}\right)$, number of roots per plant $(7.693 \pm 0.0114)$, dry root weight $(0.7215 \pm 0.0001)$, shoot dry weight $0.9763 \pm 0.0022 \mathrm{~g})$ root length $(1.923 \pm 2.0923 \mathrm{~cm})$ and shoot length $(1.326 \pm 1.0223 \mathrm{~cm})$ under all of the drought treatments. The coefficient of variation was found lower for all of the studied traits which revealed the consistency among the results and showed that the results were reliable for the selection of maize genotypes for drought stress tolerance to improve grain yield and productivity of maize crop plants under drought stress environmental conditions. The genetic advance was found higher for all of the studied traits while highest were recorded for root length $(28.252 \%)$ and shoot length $(24.132 \%)$. The

\section{Results and discussion}

It was found from results shown in table 1 that all of the maize genotypes were affected by water deficiency or drought stress conditions. The survival rate of all of the genotypes was $100 \%$ under normal or control conditions, while the survival rate was decreased as the shortage of water was exposed to the seedlings; the higher survival rate at lowest irrigation water was recorded for maize genotypes B-316 and Raka-poshi, while the lowest survival rate was recorded for Pak-afghoi. The higher survival rate of B-316 and Raka-poshi indicated that these genotypes showed tolerance for drought stress conditions and may be used for the development of higher yielding maize hybrids and synthetic varieties (Ali et al., 2012; Boomsma et al., 2009). higher genetic advance for root length and shoot length indicated the selection of drought tolerance maize genotypes on the basis of root length and shoot length may be helpful to improve maize grain yield under drought stress conditions (Farre and Faci, 2006; Mustafa et al., 2013). The higher genetic advance also revealed that the shoot length and root length may be fixed in next generation hence may be used as selection criteria. The higher heritability was also found for all of the studied traits, while again higher heritability was recorded for root length (91.298\%) and shoot length $(92.145 \%)$, the higher heritability indicated that the genes for traits will be inherited to next generation for improvement of root and shoot lengths. The selection on the basis of higher heritability may be used for the development of hybrids and synthetic varieties of maize (Ali et al., 2012; Ali et al., 2011; Boomsma et al., 2009).

Table 2. Genetic components for morphological traits of maize seedlings

\begin{tabular}{lllllll}
\hline Source & LA & RPP & DRW & DSW & RL & SL \\
\hline Replication & 0.0002 & 0.0318 & 0.00063 & 0.0023 & 0.0342 & 0.0134 \\
Genotypes & $6.0023^{*}$ & $1.6371^{*}$ & $0.00053^{*}$ & $0.0036^{*}$ & $64.002^{*}$ & $26.246^{*}$ \\
Treatments & $8.436^{*}$ & $1.3084^{*}$ & $0.01873^{*}$ & $0.01672^{*}$ & $6.8624^{*}$ & $7.4317^{*}$ \\
Genotypes $\times$ treatments & $21.543^{*}$ & $1.4464^{*}$ & $0.00478^{*}$ & $0.00148^{*}$ & $0.0871^{*}$ & $0.017^{*}$ \\
Error & 0.0213 & 0.00897 & 0.00003 & 0.0003 & 0.0197 & 0.0342
\end{tabular}

[Citation: Haseeb, A., Nawaz, A., Rao, M.Q.A., Ali, Q., Malik, A. (2020). Genetic variability and association among seedling traits of Zea mays under drought stress conditions. Biol. Clin. Sci. Res. J., 2020: 20 doi: https://doi.org/10.54112/bcsrj.v2020i1.20] 


$\begin{array}{lllllll}\text { Grand Mean } & 4.1522 & 7.693 & 0.7215 & 0.9763 & 19.923 & 19.326 \\ \text { Coefficient of variance (\%) } & 7.464 & 8.231 & 9.26 & 7.242 & 10.23 & 5.32 \\ \text { Standard Error } & 0.00112 & 0.0114 & 0.0001 & 0.0022 & 2.0923 & 1.0223 \\ \text { Genetic advance } & 21.234 & 15.891 & 17.245 & 23.981 & 28.252 & 24.132 \\ \text { Broad sense heritability } & 87.242 & 83.109 & 89.435 & 90.131 & 91.298 & 92.145\end{array}$

* = Significant at 5\% probability level, DRW = dry root weight, $\mathrm{FRW}=$ fresh root weight, $\mathrm{RL}=$ root length, $\mathrm{SL}=$ shoot length, $\mathrm{RPP}=$ roots per plant, $\mathrm{LA}=$ leaf area

The table 3 showed that the all of the genotype Bwith other genotypes. The higher root and shoot 316, Raka-poshi, EV-1097Q and Pak-afghoi showed varying behavior under all treatments of drought stress on maize seedlings, the results indicated that the genotypes B-316 and Raka-poshi showed higher root length and shoot length under lowest irrigation lengths of both of the genotypes indicated that the selection of these two genotypes may be effective for developing drought tolerant maize varieties and hybrids (Ali et al., 2014; Mazhar et al., 2020; Saif-ulwater treatment of $20 \%$ irrigation water as compared malook et al., 2014; Zameer et al., 2015).

Table 3. Mean comparison for maize genotypes under different salt concentrations

\begin{tabular}{|c|c|c|c|c|c|c|c|}
\hline Genotypes & Treatments & SL & RL & LA & NR & SDW & RDW \\
\hline \multicolumn{8}{|l|}{ B-316 } \\
\hline & Control (T0) & $18.760 \mathrm{~b}$ & $17.560 \mathrm{c}$ & $5.170 \mathrm{~b}$ & $7.560 \mathrm{a}$ & $0.980 \mathrm{a}$ & $0.775 \mathrm{a}$ \\
\hline & $20 \%$ irrigation water (T1) & $19.950 \mathrm{a}$ & $19.100 \mathrm{a}$ & $5.280 \mathrm{a}$ & $5.160 \mathrm{e}$ & $0.875 \mathrm{~d}$ & $0.676 \mathrm{~d}$ \\
\hline & $40 \%$ irrigation water (T2) & $18.758 b$ & $17.560 \mathrm{c}$ & $5.360 \mathrm{a}$ & $5.360 \mathrm{~d}$ & $0.878 \mathrm{~d}$ & $0.680 \mathrm{c}$ \\
\hline & $60 \%$ irrigation water (T3) & $18.760 \mathrm{~b}$ & $18.160 \mathrm{~b}$ & $4.570 \mathrm{~d}$ & $6.260 \mathrm{~b}$ & $0.990 \mathrm{~b}$ & $0.681 \mathrm{c}$ \\
\hline & $80 \%$ irrigation water (T5) & $18.759 b$ & $18.260 \mathrm{~b}$ & $4.250 \mathrm{~d}$ & $6.160 \mathrm{~b}$ & $0.990 b$ & $0.669 \mathrm{e}$ \\
\hline & $90 \%$ irrigation water (T6) & $18.302 \mathrm{c}$ & $17.347 \mathrm{c}$ & $4.989 \mathrm{c}$ & $6.012 \mathrm{c}$ & $0.942 \mathrm{c}$ & $0.692 \mathrm{~b}$ \\
\hline \multicolumn{8}{|c|}{ Raka-poshi } \\
\hline & Control (T0) & $17.579 \mathrm{c}$ & $18.440 \mathrm{c}$ & $5.710 \mathrm{c}$ & $7.210 \mathrm{a}$ & $0.950 \mathrm{c}$ & $0.729 \mathrm{c}$ \\
\hline & $20 \%$ irrigation water (T1) & $19.010 \mathrm{a}$ & $17.140 \mathrm{~d}$ & $5.901 \mathrm{~b}$ & $5.243 \mathrm{e}$ & $0.860 \mathrm{e}$ & $0.650 \mathrm{~d}$ \\
\hline & $40 \%$ irrigation water (T2) & $18.606 \mathrm{~b}$ & $17.540 \mathrm{~d}$ & $5.410 \mathrm{e}$ & $6.310 \mathrm{c}$ & $0.858 \mathrm{f}$ & $0.648 \mathrm{e}$ \\
\hline & $60 \%$ irrigation water (T3) & $18.609 \mathrm{~b}$ & $17.520 \mathrm{~d}$ & $5.633 \mathrm{~d}$ & $6.210 \mathrm{~d}$ & $0.960 \mathrm{~b}$ & $0.649 \mathrm{e}$ \\
\hline & $80 \%$ irrigation water (T5) & $17.579 \mathrm{c}$ & $21.140 \mathrm{a}$ & $6.150 \mathrm{a}$ & $6.410 \mathrm{~b}$ & $0.938 \mathrm{~d}$ & $0.741 \mathrm{a}$ \\
\hline & $90 \%$ irrigation water (T6) & $17.341 \mathrm{~d}$ & $19.23 \mathrm{~b}$ & $5.231 \mathrm{f}$ & $6.135 \mathrm{~d}$ & $0.974 \mathrm{a}$ & $0.734 \mathrm{~b}$ \\
\hline \multicolumn{8}{|c|}{ EV-1097Q } \\
\hline & Control (T0) & $19.567 \mathrm{a}$ & $18.320 \mathrm{c}$ & $5.24 \mathrm{~d}$ & $7.960 \mathrm{a}$ & $0.928 b$ & $0.739 \mathrm{a}$ \\
\hline & $20 \%$ irrigation water (T1) & $18.56 \mathrm{~b}$ & $18.32 \mathrm{c}$ & $5.26 \mathrm{c}$ & $7.86 \mathrm{a}$ & $0.833 \mathrm{~d}$ & $0.613 d$ \\
\hline & $40 \%$ irrigation water (T2) & $17.54 \mathrm{c}$ & $19.54 \mathrm{a}$ & $6.35 \mathrm{a}$ & $6.96 \mathrm{~b}$ & $0.809 \mathrm{e}$ & $0.731 \mathrm{~b}$ \\
\hline & $60 \%$ irrigation water (T3) & $17.541 \mathrm{c}$ & $19.31 \mathrm{a}$ & $6.35 \mathrm{a}$ & $6.86 \mathrm{~b}$ & $0.908 \mathrm{c}$ & $0.733 b$ \\
\hline & $80 \%$ irrigation water (T5) & $18.562 \mathrm{~b}$ & $19.13 b$ & $5.36 \mathrm{c}$ & $6.86 \mathrm{~b}$ & $0.933 \mathrm{a}$ & $0.732 b$ \\
\hline & $90 \%$ irrigation water (T6) & $18.23 \mathrm{~d}$ & $18.34 \mathrm{c}$ & $6.214 b$ & $6.90 \mathrm{~b}$ & $0.903 \mathrm{c}$ & $0.721 \mathrm{c}$ \\
\hline \multicolumn{8}{|c|}{ Pak-afghoi } \\
\hline & Control (T0) & $17.422 \mathrm{~d}$ & $17.74 \mathrm{c}$ & $7.426 \mathrm{a}$ & $7.652 \mathrm{a}$ & $0.932 \mathrm{a}$ & $0.722 \mathrm{a}$ \\
\hline & $20 \%$ irrigation water (T1) & $18.522 \mathrm{a}$ & $18.624 \mathrm{~b}$ & $6.351 \mathrm{~d}$ & $5.124 \mathrm{f}$ & $0.821 \mathrm{~d}$ & $0.614 d$ \\
\hline & $40 \%$ irrigation water (T2) & $19.512 b$ & $17.528 \mathrm{~d}$ & $6.504 \mathrm{c}$ & $6.043 \mathrm{e}$ & $0.811 \mathrm{~d}$ & $0.625 c$ \\
\hline & $60 \%$ irrigation water (T3) & $17.421 \mathrm{~d}$ & $18.516 \mathrm{~b}$ & $6.503 \mathrm{c}$ & $6.164 d$ & $0.921 \mathrm{~b}$ & $0.727 \mathrm{a}$ \\
\hline & $80 \%$ irrigation water (T5) & $18.432 \mathrm{c}$ & $17.452 \mathrm{~d}$ & $7.143 b$ & $6.405 b$ & $0.901 \mathrm{c}$ & $0.711 \mathrm{~b}$ \\
\hline & $90 \%$ irrigation water (T6) & $17.241 \mathrm{e}$ & $19.234 \mathrm{a}$ & $6.342 \mathrm{e}$ & $6.325 \mathrm{c}$ & $0.930 \mathrm{a}$ & $0.712 b$ \\
\hline
\end{tabular}

$\mathrm{DRW}=$ dry root weight, $\mathrm{FRW}=$ fresh root weight, $\mathrm{RL}=$ root length, $\mathrm{SL}=$ shoot length, $\mathrm{RPP}=$ roots per plant, $\mathrm{LA}=$ leaf area

From correlation analysis (Table 4) a positive and significant correlation was recorded for shoot length with all of the studied traits including root length, leaf area, number of roots per plant, dry root weight and dry shoot weight. The root length was significantly correlated with leaf area, shoot length while negative and significant correlation of root length was recorded with dry root weight. The positive correlation of root length and shoot length indicated that under water deficit conditions the seedlings may withstand for long time and can survive even under harsh environmental conditions. The election on the basis of root length and shoot length may be helpful to improve drought stress

[Citation: Haseeb, A., Nawaz, A., Rao, M.Q.A., Ali, Q., Malik, A. (2020). Genetic variability and association among seedling traits of Zea mays under drought stress conditions. Biol. Clin. Sci. Res. J., 2020: 20 doi: https://doi.org/10.54112/bcsrj.v2020i1.20] 
tolerance in maize and also help to develop drought 2014). tolerant maize genotypes (Ali et al., 2016; Ali et al.,

Table 4. Correlation among morphological traits of maize

\begin{tabular}{llllll}
\hline Traits & LA & RPP & DRW & DSW & RL \\
\hline RPP & $0.6324 *$ & & & & \\
DRW & -0.0243 & 0.0942 & & & \\
DSW & -0.1354 & 0.2045 & $0.3562 *$ & & \\
RL & $0.5362 *$ & 0.2845 & $-0.3565 *$ & -0.3023 & \\
SL & $0.4822^{*}$ & $0.5353 *$ & $0.7632 *$ & $0.8753 *$ & $0.6872 *$ \\
\hline
\end{tabular}

$*=$ Significant at $5 \%$ probability level, DRW = dry root weight, $\mathrm{FRW}=$ fresh root weight, $\mathrm{RL}=$ root length, $\mathrm{SL}=$ shoot length, RPP = roots per plant, LA = leaf area

Regression analysis was performed to evaluate the contribution of each studied trait for improving shoot length under drought stress conditions. It was found from our results (Table 5) that the root length contributed higher towards increasing shoot length as compared with other traits (Ali et al., 2016; Cakir, 2004; Mustafa et al., 2018), the leaf area and dry shoot weight also contributed positively towards shoot length while the dry root weight and number of roots per plant contributed negatively towards shoot length of maize seedlings. The predicted regression equation was as following: $\mathrm{Y}=1.217+8.126(\mathrm{RL})+$ $3.714(\mathrm{LA})-2.420(\mathrm{DRW})+5.4123(\mathrm{DSW})-$ $1.324(\mathrm{RPP})$

Table 5. Regression analysis for shoot length among morphological traits of maize

\begin{tabular}{lllllll}
\hline Traits & Coefficients & $\begin{array}{l}\text { Standard } \\
\text { Error }\end{array}$ & t Stat & Partial R & $\begin{array}{l}\text { Lower } \\
\mathbf{9 5 \%}\end{array}$ & $\begin{array}{l}\text { Upper } \\
\mathbf{9 5 \%}\end{array}$ \\
\hline RL & 8.126 & 0.052 & -0.0152 & 0.7623 & 0.0363 & 0.0136 \\
LA & 3.714 & 0.1102 & 0.0314 & 0.4162 & 0.0117 & 0.3104 \\
DRW & -2.420 & 0.0042 & 2.0013 & 0.1556 & -0.0315 & 0.3055 \\
DSW & 5.4123 & 0.0212 & -5.3336 & 0.0323 & 2.1146 & 1.3012 \\
RPP & -1.324 & 0.0114 & 0.2103 & 0.4332 & -0.0135 & 0.0136 \\
\hline
\end{tabular}

$\mathrm{Y}=1.217$, Multiple $\mathrm{R}^{2}=0.8534, \mathrm{R}^{2}=0.6823$, Adjusted $\mathrm{R}^{2}=0.6424$, Standard Error $=0.0231 \mathrm{DRW}=\mathrm{dry}$ root weight, FRW = fresh root weight, $\mathrm{RL}=$ root length, $\mathrm{RPP}=$ roots per plant, $\mathrm{LA}=$ leaf area

\section{Conclusions}

It was found that the genotypes B-316 and Rakaposhi showed better performance for all studied traits especial shoot and root length as compared with other two genotypes EV-109Q and Pak-Afghoi. The minimum effects of drought were reported at control and $90 \%$ irrigation water. The effects of drought were increased with the increase in concentration of drought stress. It was concluded from study that the selection of maize genotypes on the basis of root length, shoot length and dry shoot weight may be fruitful to produce drought stress tolerance maize hybrids and synthetic varieties.

\section{Conflict of interest}

The authors declare absence of any conflict of interest.

\section{References}

Ali, Q., Ahsan, M., Ali, F., Aslam, M., Khan, N. H., Munzoor, M., Mustafa, H. S. B., and Muhammad, S. (2013). Heritability, heterosis and heterobeltiosis studies for morphological traits of maize (Zea mays L.) seedlings. Advancements in Life sciences $\mathbf{1}$.
Ali, Q., Ahsan, M., Kanwal, N., Ali, F., Ali, A., Ahmed, W., Ishfaq, M., and Saleem, M. (2016). Screening for drought tolerance: comparison of maize hybrids under water deficit condition. Advancements in Life Sciences 3, 51-58.

Ali, Q., Ahsan, M., Tahir, M. H. N., and Basra, S. M. A. (2012). Genetic evaluation of maize (Zea mays L.) accessions for growth related seedling traits. International Journal for Agro Veterinary and Medical Sciences 6, 164-172.

Ali, Q., Ali, A., Ahsan, M., Nasir, I. A., Abbas, H. G., and Ashraf, M. A. (2014). Linex Tester analysis for morpho-physiological traits of Zea mays $\mathrm{L}$ seedlings. Advancements in Life sciences 1, 242-253.

Ali, Q., Hammad, M., Tahir, N., Ahsan, M., Basra, S. M. A., Farooq, J., and Elahi, M. (2011). Correlation and path coefficient studies in maize (Zea mays L.) genotypes under $40 \%$ soil moisture contents. African Journal of Bacteriology Research 3, 77-82.

Barnabás, B., Jäger, K., and Fehér, A. (2008). The effect of drought and heat stress on reproductive processes in cereals. Plant, cell \& environment 31, 11-38.

[Citation: Haseeb, A., Nawaz, A., Rao, M.Q.A., Ali, Q., Malik, A. (2020). Genetic variability and association among seedling traits of Zea mays under drought stress conditions. Biol. Clin. Sci. Res. J., 2020: 20 doi: https://doi.org/10.54112/bcsrj.v2020i1.20] 
Boomsma, C. R., Santini, J. B., Tollenaar, M., and Vyn, T. J. (2009). Maize morphophysiological responses to intense crowding and low nitrogen availability: An analysis and review. Agronomy Journal 101, 1426-1452.

Buckler, E. S., Holland, J. B., Bradbury, P. J., Acharya, C. B., Brown, P. J., Browne, C., Ersoz, E., Flint-Garcia, S., Garcia, A., and Glaubitz, J. C. (2009). The genetic architecture of maize flowering time. Science 325, 714-718.

Cakir, R. (2004). Effect of water stress at different development stages on vegetative and reproductive growth of corn. Field Crops Research 89, 1-16.

Chai, Q., Gan, Y., Zhao, C., Xu, H.-L., Waskom, R. M., Niu, Y., and Siddique, K. H. (2016). Regulated deficit irrigation for crop production under drought stress. A review. Agronomy for sustainable development 36, 3 .

Chaudhary, A. (1983). Effect of population and control of weeds with herbicides in maize. Field Crop Abst 35, 403.

Edreira, J. I. R., and Otegui, M. E. (2012). Heat stress in temperate and tropical maize hybrids: Differences in crop growth, biomass partitioning and reserves use. Field Crops Research 130, 87-98.

Farre, I., and Faci, J. M. (2006). Comparative response of maize (Zea mays L.) and sorghum (Sorghum bicolor L. Moench) to deficit irrigation in a Mediterranean environment. Agricultural water management 83, 135-143.

Masood, S. A., Jabeen, S., Anum, M., Naseem, Z., Jamshaid, A., and Ali, Q. (2015). Genetic Association of transcriptional factors (OsAP2 gene family) to incorporate drought tolerance in rice. Life Science Journal 12, 71-76.

Mazhar, T., Ali, Q., and Malik, M. S. R. A. (2020). Effects of salt and drought stress on growth traits of Zea mays seedlings. Life Science Journal 17.

Mupangwa, W., Twomlow, S., Walker, S., and Hove, L. (2007). Effect of minimum tillage and mulching on maize (Zea mays L.) yield and water content of clayey and sandy soils. Physics and chemistry of the earth, parts $A / B / C$ 32, 1127-1134.

Mustafa, H. S. B., Ahsan, M., Aslam, M., Ali, Q., Bibi, T., and Mehmood, T. (2013). Genetic variability and traits association in maize (Zea mays L.) accessions under drought stress. Journal of Agricultural Research (03681157) 51.
Mustafa, H. S. B., Mahmood, T., Hameed, A., and Ali, Q. (2018). Enhancing food security in arid areas of Pakistan through newly developed drought tolerant and short duration mustard (Brassica juncea L.) Canola. Genetika 50, 2131.

Saif-ul-malook, M. A., Ali, Q., and Mumtaz, A. (2014). Inheritance of yield related traits in maize (Zea mays) under normal and drought conditions. Nat Sci 12, 36-49.

Zameer, M., Munawar, S., Tabassum, B., Ali, Q., Shahid, N., Saadat, H. B., and Sana, S. (2015). Appraisal of various floral species biodiversity from Iskandarabad, Pakistan. Life Sci J 12, 7787.

Zubair, M., Shakir, M., Ali, Q., Rani, N., Fatima, N., Farooq, S., Shafiq, S., Kanwal, N., Ali, F., and Nasir, I. A. (2016). Rhizobacteria and phytoremediation of heavy metals. Environmental Technology Reviews 5, 112-119.

\section{(c) (9) \&}

Open Access This article is licensed under a Creative Commons Attribution 4.0 International License, which permits use, sharing, adaptation, distribution and reproduction in any medium or format, as long as you give appropriate credit to the original author(s) and the source, provide a link to the Creative Commons licence, and indicate if changes were made. The images or other third party material in this article are included in the article's Creative Commons licence, unless indicated otherwise in a credit line to the material. If material is not included in the article's Creative Commons licence and your intended use is not permitted by statutory regulation or exceeds the permitted use, you will need to obtain permission directly from the copyright holder. To view a copy of this licence, visit http://creativecommons.org/licen ses/by/4.0/.

(C) The Author(s) 2021

[Citation: Haseeb, A., Nawaz, A., Rao, M.Q.A., Ali, Q., Malik, A. (2020). Genetic variability and association among seedling traits of Zea mays under drought stress conditions. Biol. Clin. Sci. Res. J., 2020: 20 doi: https://doi.org/10.54112/bcsrj.v2020i1.20] 